71 巻 701 号 $(2005-1)$

\title{
加熱/冷却一体形プレートを用いたフォトレジストプロセス におけるウェハの任意熱履歴制御*
}

\author{
板 東 賢 一*1, 箕 西 幹夫*2, 横田 眞 -*3
}

\section{Arbitrary Thermal History Control of Wafer in Photo Resist Processing Using Integrated Heating and Cooling Plate}

\author{
Kenichi BANDOH ${ }^{* 4}$, Mikio MINONISHI and Shinichi YOKOTA \\ ${ }^{* 4}$ Innovation Center 2, Research Division KOMATSU Ltd., \\ 1200 Manda, Hiratsuka-shi, Kanagawa, 254-8567 Japan
}

\begin{abstract}
For photo resist processing in semiconductor manufacturing, the precise temperature control of wafer has been demanded to realize a more fine device in recent years. However, it is difficult to achieve the precise temperature control by a current wafer heating and cooling system, because the system cannot control the temperature of transient state including wafer movement from the nature of the system. An integrated heating and cooling plate was developed to overcome above problem. On the other hand, it is difficult to achieve the precise temperature control of the plate because of its mutual intervention and unstable non-steady heat conduction. For that reason, we propose the control system based on thermal model with finite element in this paper, which is the state feedback control with scheduled gain to the process progress. Moreover, we propose the in-process estimation of wafer temperature based on system identification. Experimental results illustrate the effectiveness of the proposed method and the arbitrary thermal history control of wafer.
\end{abstract}

Key Words : Process Control, Modeling, Observer, Integrated Heating and Cooling Plate, Photo Resist Processing, In-Process Estimation

\section{1. 粕 臬}

現在，半導体製造におけるフォトレジストプロセ ス(レジスト塗布, 現像等)では, 半導体デバイスの微 細化(線幅 $100[\mathrm{~nm}])$ に対応するため, 厳しい温度管理が 要求されている(1). 特に, 露光パターン寸法は, ウェ 八の露光後の加熱処理温度(Post Exposure Bake ; PEB 温 度)に強く依存する．例えば，あるレジストのライン パターン寸法は, PEB 温度に対して, 約 $4\left[\mathrm{~nm} /{ }^{\circ} \mathrm{C}\right]$ もの 寸法変動を生じる. これより, パターン寸法精度の向 上には，ウェ八面内温度を厳密に制御する必要がある. また, ウェハ毎のパターン寸法の再現性には, ウェハ 毎の温度差を極力低減させることが必要である(2).

現在のフォトレジストプロセスにおけるウェハの 加熱冷却システムは，個別のチャンバー内にある加 熱プレート, 冷却プレート(それぞれ一定温度に制御) およびウェ八搬送用ロボットから構成されている．熱

* 原稿受付 2004 年 4 月 16 日

*1 正員, (株)小松製作所研究本部( - 254-8567 平塚市万田 1200).

*2 (株) 小松製作所研究本部.

*3 正員, 東京工業大学精密工学研究所 ( $3226-8503$ 横浜市緑区 長津田町 4259)

E-mail : kenichi_bandou@komatsu.co.jp
処理されるウェハは，搬送用ロボットにより加熱プレ 一ト上に載せられ，加熱用チャンバー内にて所定温度 (高温)で所定時間加熱される. その後, 搬送用ロボッ トにより加熱用チャンバーから取り出されたウェハは, 冷却プレート上に載せられ，冷却用チャンバー内にて 所定温度(常温近傍)に泠却される(3)(4).

このシステムの問題点として，常温のウェハを加 熱プレートに載せたときと加熱された高温のウェハを 冷却プレ一トに載せたときに生じる大きなウェハ面内 温度分布, 加熱プレートから冷却プレートへのウェハ 搬送時に，ウェハに与える熱履歷を厳密に管理できな いこと等がある．また，搬送時に生じるチャンバー内 のコンタミネーションも問題となる. さらに，多品種 少量生産のプロセスにおいては，加熱プレートの設定温 度変更に要する時間を短縮して，生産性を向上させるこ とが望まれている(

加熱冷却一体形プレートは，上記のような問題点 を解決するために提案された新しい構造をもつ半導体 製造用プレートである(6). 本プレートによって， ウェ 八は，一つのチャンバー内で搬送されることなく加熱 伶却処理が完了し，厳密な温度管理が可能になる.

本報では，この加熱泠却一体形プレートを用いた 
フォトレジストプロセスにおけるウェハの高精度な温 度制御手法の確立をおこなう。しかし, 本プレートは, その構造から，大きな相互干渉を有する多入出力系で あり，また，熱的に不安定な分布定数系である.この ため, ウェハの高精度な温度制御を実現することが困 難である，そこで，本報では，対象の伝熱特性の相違 により最小限に要素分割された物理モデル(以後, 有 限要素伝熱モデルと呼ぶ)を用いて非定常な伝熱を推 定し，そのフィードバックとゲインスケジュールによ って高精度な温度制御を実現する制御手法を提案する. また，本報では，実プロセスにおいてインプロセ ス計測が困難なウェ八温度を, 計測可能なプレート温 度を用いて推定するソフトウェアセンシング技術(以 後, ウェ八温度推定器)を提案する. ウェ八温度推定 器は, システム同定理論を応用することによって実現 される. 本提案手法によって, ウェ八温度の高精度な 推定および制御が実現される. 上記提案手法の有效性 が，実験によって示される.

\section{2. 加熱・冷却一体形プレート}

図 1 に現在の加熱冷却システムと加熱泠却一体形 プレートを用いたシステムの比較を示す. 加熱冷却 一体形プレートを用いることによって, システムの小 形化を図ることができる。

$2 \cdot 1$ プレート構造 図 2 に $200[\mathrm{~mm}]$ ウェ八用の 加熱冷却一体形プレートの構造を示す(ただし, 図 2 は図 1 と異なり, 冷却液の出入口が一䇢所に集中して いる)。このプレートは, 厚さ $5[\mathrm{~mm}]$ のプレート形熱 交換器と厚さ $25[\mu \mathrm{m}]$ の薄膜ヒータから構成されてい る. ウェ八は, 薄膜ヒータによって加熱され, プレー 卜形熱交換器に冷却液を流すことによって冷却される。 プレート形熱交換器は, 内部に冷却液の流れる流路と ピンフィンをもつ. 薄膜ヒータは, 加熱時のウェ八面 内温度分布を高精度に制御するため, 図 2 のように 3 ゾーンに分割されている. 3 つのゾーンは, ウェ八直 径よりも若干大きい直径の中央ゾーン(ソ゚ーン 2), プ レート外周を覆うリング状の外周ゾーン(ゾーン 1), 冷却液の出入口を覆う突出ゾーン (ゾーン 3)に分割さ れている.このゾーン分割の形状は, 有限要素法によ る伝熱解析によって, 加熱過渡状態におけるウェ八面 内温度分布の Range $\left[ \pm^{\circ} \mathrm{C}\right](=($ (最大温度 $)-($ 最小温度 $\left.)) 2\right)$ が最小になるように設計された，そして，各ゾーンは， プレート内部にある3つの白金測温抵抗体により計測 された温度を用いて個別に制御される.ただし， 3 つ の白金測温抵抗体は, 後述するウェ八温度推定器によ りゾーン 2 上に載せられたウェ八温度を高精度に推定

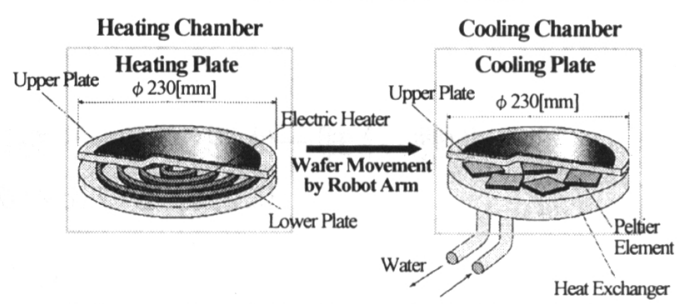

(a) Conventional Heating and Cooling System

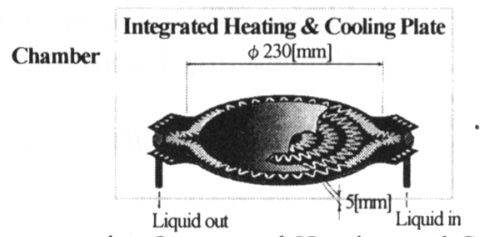

(b) System using Integrated Heating and Cooling Plate

Fig.1 Comparison of System

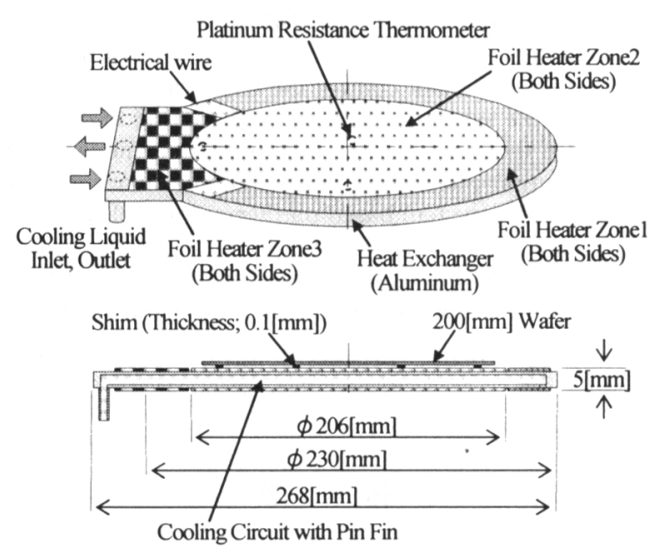

Fig.2 Plate Structure

するために, すべてゾーン 2 の領域内にある.

$2 \cdot 2$ 実験装置 図 3 に加熱/冷却一体形プレー トの実験装置の概略を示す。冷却液用の温度調節器 (冷却液を循環させるためのポンプ等を含む)は，加熱 時にプレート内部で高温になった液体を椧却し, プレ 一トに供給される泠却液の温度を一定(ウェハの椧却 目標温度よりも $\left.1.5 \sim 3.00^{\circ} \mathrm{C}\right]$ 低い温度)に保つ. 椧却液 は, 絶縁性を有し, 沸点が $200\left[{ }^{\circ} \mathrm{C}\right]$ のフッ素系不活性 液体(ガルデン HT200 ; ソルベイソレクシス社製)を用 いる. ステッピングモータは, 熱処理前後のウェ八を 搬送用ロボットに受け渡しする際, 昇降ピンを駆動し て, ウェハを上下動させるために用いられる.

ウェハ泠却プロセスにおいて，3つの白金測温抵抗 体により計測された温度のいずれかが，ウェハの泠却 目標温度よりも $0.7\left[^{\circ} \mathrm{C}\right]$ 低い温度に到達したとき, オン オフ弁 2を閉から開にすることによって冷却液流量が 6[V/min]から 3[V/min]に减らされる. 冷却定常状態では, 冷却目標温度より低くなったプレート温度を薄膜ヒー 


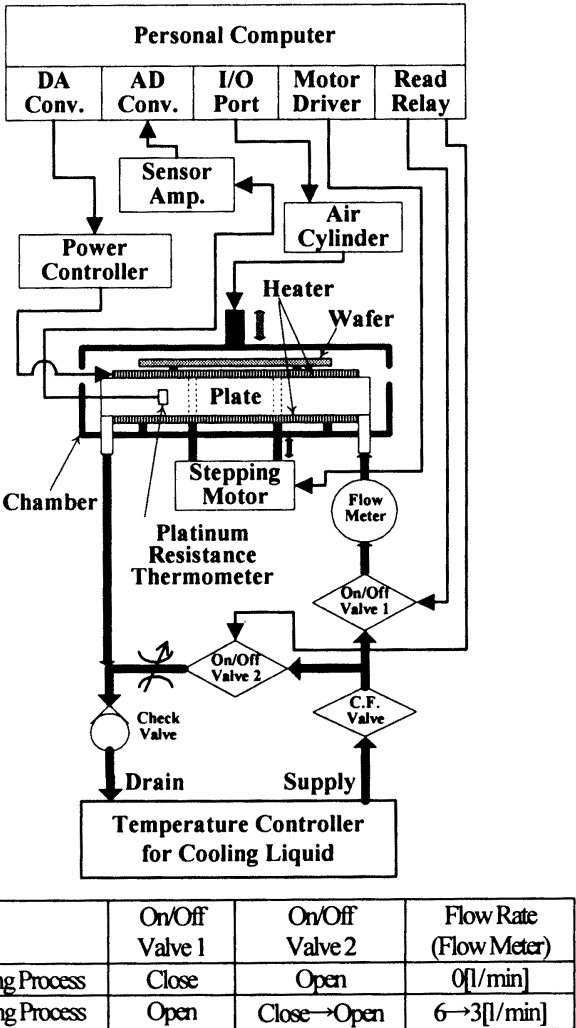

Fig.3 Experimental Apparatus

タで加熱することによって目標温度に制御する．その 際の薄膜ヒータへの供給電力は, 冷却液流量を 6[V/min]から 3[V/min]にすることで低减できる.

\section{3. 制 御 系 設 計}

図 2 の加熱冷却一体形プレートは, 薄膜ヒータの ゾーン分割と白金測温抵抗体の位置関係から，大きな 相互干渉を有する多入出力系である. また，冷却液の 出入口の配管およびプレート内部の冷却液の温度は, プロセス中に定常状態になることはなく，不安定な非 定常伝熱が常に存在する。このような制御対象に対し て，その伝熱特性の違いにより最小限に要素分割され た有限要素伝熱モデルを用いて制御系を設計し，精密 なウェハ温度制御の実現を図る、測定された温度のみ を用いて制御した場合，ゾーン 1 およびゾーン 3 の薄膜 ヒータからウェハまでの伝熱の遅れのため, 精密なウェ 八温度制御が困難である.

$3 \cdot 1$ 有限要素伝熱モデル 加熱伶却一体形プ レート(ウェハ含む)を図 4 のように 9 つの要素に分割 して伝熱モデルを作成する．ただし，これは，加熱時 の伝熱モデルプレートへの冷却液供給を止めた状態）

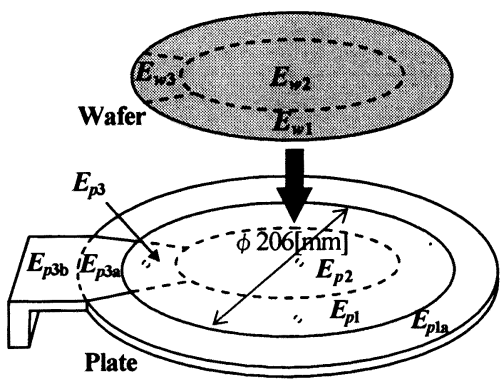

Fig.4 Thermal Model with Finite Element

である．冷却時は，冷却液およびチャンバー内温度が 目標温度近傍であるため, ゾーン 1 およびゾーン 3 の 温度制御によって，ウェハ周りの放熱を厳密に制御す る必要がない，よって，ここでは，加熱時の伝熱モデ ルのみを考える．要素の分割は，薄膜ヒータの分割に 加えて, ゾーン 2 を白金測温抵抗体の位置(ゾーン 1, ゾーン 3 との相互干渉が存在する位置)に応じて 3 つ に分割する $\left(E_{p 2}, E_{p 1}, E_{p 3}\right)$. さらに, ゾーン 3 をウェハ 近傍の要素と配管が接続される要素の 2 つに分割する $\left(E_{p 3 \mathrm{a}}, E_{p 3 \mathrm{~b}}\right) . こ こ て ゙$ 分割した要素内に生じる温度分布 における温度差は, 有限要素法による伝熱解析では, 配管が接続される要素 $E_{p 3 \mathrm{~b}}$ 内の表面において最大 $8.2\left[{ }^{\circ} \mathrm{C}\right]$ であった. 一方, 他の要素内の表面で生じる温 度差は小さいため, 要素内の温度は均一と考える. 特 に, ウェ八の要素 $\left(E_{w 2}, E_{w 1}, E_{w 3}\right)$ 内では, 最大温度差 $0.1\left[{ }^{\circ} \mathrm{C}\right]$ であった. $3 つ$ 白金測温抵抗体により計測さ れたプレート温度から, 後述するウェハ温度推定器お よびオブザーバを用いて各要素の温度を推定するため, 分割する要素数は，できる限り少ないほうが望ましい． よって, ここでは, 要素 $E_{p 3 \mathrm{~b}}$ とプレート内部の液体 をさらに要素分割しないことにする(ただし，プレー トの熱伝導率等の物性值は, 固体部分と液体部分の体 積比で表すことにする). 要素分割で考慮していない 冷却液の出入口の配管およびプレート内部の液体への 非定常伝熱(要素内の温度差によって生じる)は, 後述 する外乱推定オブザーバにより外乱として考慮される.

図 4 によって表された有限要素伝熱モデルの状態方 程式は，つぎのようである.

$$
\begin{aligned}
& \dot{\boldsymbol{x}}=\boldsymbol{A} \boldsymbol{x}+\boldsymbol{B} \boldsymbol{u} \\
& \boldsymbol{y}=\boldsymbol{C} \boldsymbol{x} \\
& \boldsymbol{x}=\left[\begin{array}{lllllllll}
w_{2} & w_{1} & w_{3} & p_{2} & p_{1} & p_{3} & p_{1 a} & p_{3 a} & p_{3 b}
\end{array}\right]^{T} \text { (3) } \\
& \boldsymbol{u}=\left[\begin{array}{lll}
q_{z 2} & q_{z 1} & q_{z 3}
\end{array}\right]^{T}
\end{aligned}
$$


$\boldsymbol{A}=$

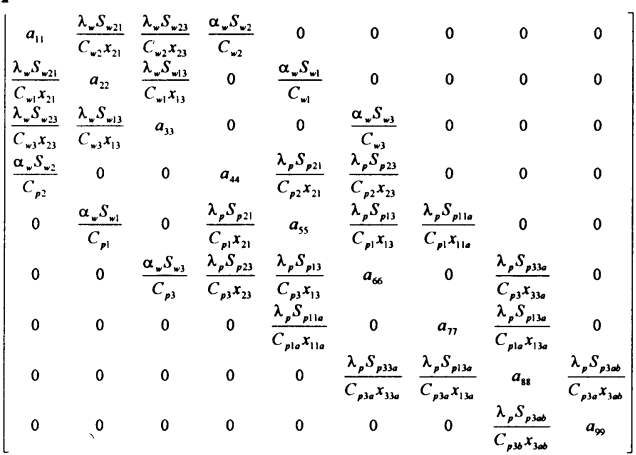

$\boldsymbol{B}=\left[\begin{array}{ccc}0 & 0 & 0 \\ 0 & 0 & 0 \\ 0 & 0 & 0 \\ \sigma_{z 2, p 2} / C_{p 2} & 0 & 0 \\ \sigma_{z 2, p 1} / C_{p 1} & 0 & 0 \\ \sigma_{z 2, p 3} / C_{p 3} & 0 & 0 \\ 0 & 1 / C_{p 1 a} & 0 \\ \sigma_{z 2, p 3 a} / C_{p 3 a} & 0 & \sigma_{z 3, p 3 a} / C_{p 3 a} \\ 0 & 0 & \sigma_{z 3, p 3 b} / C_{p 3 b}\end{array}\right], \quad \boldsymbol{C}=\left[\begin{array}{lllllllll}1 & 0 & 0 & 0 & 0 & 0 & 0 & 0 & 0 \\ 0 & 1 & 0 & 0 & 0 & 0 & 0 & 0 & 0 \\ 0 & 0 & 1 & 0 & 0 & 0 & 0 & 0 & 0 \\ 0 & 0 & 0 & 1 & 0 & 0 & 0 & 0 & 0 \\ 0 & 0 & 0 & 0 & 1 & 0 & 0 & 0 & 0 \\ 0 & 0 & 0 & 0 & 0 & 1 & 0 & 0 & 0 \\ 0 & 0 & 0 & 0 & 0 & 0 & 1 & 0 & 0 \\ 0 & 0 & 0 & 0 & 0 & 0 & 0 & 1 & 0 \\ 0 & 0 & 0 & 0 & 0 & 0 & 0 & 0 & 1\end{array}\right]$

(6)

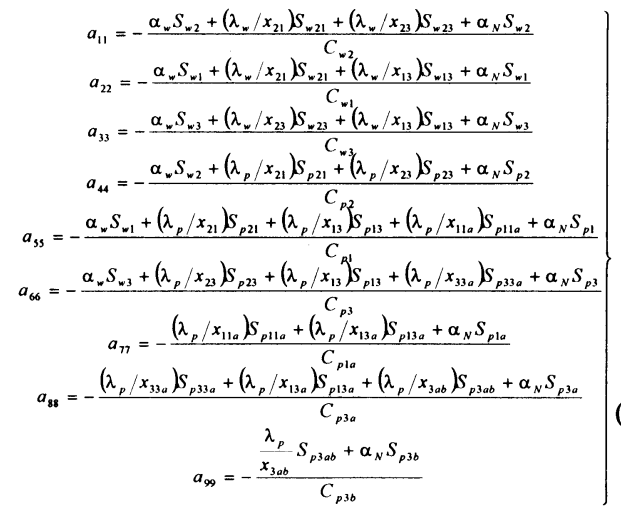

$\boldsymbol{A} \in \boldsymbol{R}^{9 \times 9}, \boldsymbol{B} \in \boldsymbol{R}^{9 \times 3}, \boldsymbol{C} \in \boldsymbol{R}^{9 \times 9}$

$w_{2}, w_{1}, w_{3} ;$ ウェハ要素の温度 $[\mathrm{K}]$

$p_{2}, p_{1}, p_{3}, p_{1 a}, p_{3 a}, p_{3 b} ;$ プレート要素の温度 $[\mathrm{K}]$

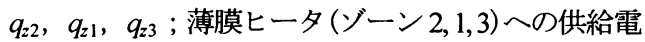
力 $[\mathrm{W}]$

$C_{i} ;$ 要素 $E_{i}$ の熱容量 $[\mathrm{J} / \mathrm{K}]$

$\alpha_{w} ;$ プレート/ウェハ間の等価熱伝達率 $\left[\mathrm{W} / \mathrm{m}^{2} \mathrm{~K}\right]$

$\alpha_{N} ;$ 外気への熱伝達率 $\left[\mathrm{W} / \mathrm{m}^{2} \mathrm{~K}\right]$

$\lambda_{w} ;$ ウェ八の熱伝導率 $[\mathrm{W} / \mathrm{mK}]$

$\lambda_{p} ;$ プレートの熱伝導率 $[\mathrm{W} / \mathrm{mK}]$

$x_{i j} ;$ 要素 $E_{i} / E_{j}$ 間の熱伝導距離 $[\mathrm{m}]$

(注記 ; たとえば, $x_{w 2 w 1}$ は $x_{21}$ と簡略して表す)

$S_{i} ;$ 要素 $E_{i}$ の外気への熱伝達面積 $\left[\mathrm{m}^{2}\right]$

$S_{i j} ;$ 要素 $E_{i} / E_{j}$ 間の熱伝導面積 $\left[\mathrm{m}^{2}\right]$
Table 1 System Parameters

\begin{tabular}{|c|c|c|}
\hline $\begin{aligned} & C_{w 2}=23.08 \\
& C_{w 1}=15.12 \\
& C_{w 3}=2.833 \\
& C_{p 2}=196.6 \\
& C_{p 1}=146.7 \\
& C_{p 3}=27.49 \\
& C_{p 1 \mathrm{a}}=77.01 \\
& C_{p 3 \mathrm{a}}=14.43 \\
& C_{p 3 \mathrm{~b}}=57.86 \\
& \alpha_{w}=281.8 \\
& \alpha_{N}=5.0 \\
& \lambda_{w}=168.0 \\
& \lambda_{p}=154.8 \\
& x_{21}=0.050 \\
& x_{23}=0.050\end{aligned}$ & $\begin{array}{l}x_{13}=0.137 \\
x_{11 \mathrm{a}}=0.020 \\
x_{33 \mathrm{a}}=0.020 \\
x_{13 \mathrm{a}}=0.171 \\
x_{3 \mathrm{ab}}=0.026 \\
S_{w 2}=0.018 \\
S_{w 1}=0.012 \\
S_{w 3}=2.169 \times 10^{-3} \\
S_{p 2}=0.018 \\
S_{p 1}=0.015 \\
S_{p 3}=2.772 \times 10^{-3} \\
S_{p 1 \mathrm{a}}=0.014 \\
S_{p 3 \mathrm{a}}=2.593 \times 10^{-3} \\
S_{p 3 \mathrm{~b}}=0.010 \\
S_{w 21}=2.877 \times 10^{-4} \\
S_{w 23}=5.390 \times 10^{-5}\end{array}$ & $\begin{array}{l}S_{w 13}=3.625 \times 10^{-5} \\
S_{p 21}=1.984 \times 10^{-3} \\
S_{p 23}=3.718 \times 10^{-4} \\
S_{p 13}=2.800 \times 10^{-4} \\
S_{p 11 \mathrm{a}}=2.725 \times 10^{-3} \\
S_{p 33 \mathrm{a}}=5.105 \times 10^{-4} \\
S_{p 13 \mathrm{a}}=1.200 \times 10^{-4} \\
S_{p 3 \mathrm{ab}}=5.700 \times 10^{-4} \\
\sigma_{z 2, p 2}=0.527 \\
\sigma_{z 2 p 1}=0.393 \\
\sigma_{z 2 p 3}=0.074 \\
\sigma_{z 2 p 3 a}=0.006 \\
\sigma_{z 3 p 3 a}=0.408 \\
\sigma_{z 3 p 3 b}=0.592\end{array}$ \\
\hline
\end{tabular}

(注記 ; たとえば, $S_{w 2 w 1}$ は $S_{w 21}$ と簡略して表す)

$\sigma_{z 2 \_}, \quad \sigma_{z 3 \_}$; 要素 $i$ を覆う薄膜ヒータ(ゾーン 2, 3)

の割合 $\left(\sigma_{z 2, p 2}+\sigma_{z 2, p 1}+\sigma_{z 2, p 3}+\sigma_{z 2, p 3 a}=1\right.$,

$\left.\sigma_{z 3, p 3 a}+\sigma_{z 3, p 3 b}=1\right)$

ここで, $u \in R^{3}, x \in R^{9}, y \in R^{9}$ は, それぞれ入力, 状態，出力である．上記システムパラメータすべての值 を表1に示す。

\section{$3 \cdot 2$ 内部モデル原理に基づくサーボ系の構成}

まず，ステップ目標值や外乱に対して定常偏差が残らな いようにするため, 有限要素伝熱モデル(1),(2)式を用 いてウェ八温度 $\boldsymbol{y}_{w}=\left[\begin{array}{lll}w_{2} & w_{1} & w_{3}\end{array}\right]^{T} \in \boldsymbol{R}^{3}$ に対するサ一ボ系 を内部モデル原理に基づき構成する. このとき，内部モ デルへの入力を $\boldsymbol{r}=\left[\begin{array}{lll}r_{2} & r_{1} & r_{3}\end{array}\right]^{T} \in \boldsymbol{R}^{3}$, 積分器のゲイン $[\mathrm{W} / \mathrm{K}]$ を $\boldsymbol{k}=\left[\begin{array}{lll}k_{2} & k_{1} & k_{3}\end{array}\right]^{T} \in \boldsymbol{R}^{3}$ とすると, サーボ系はつぎ のように表されるあ.

$$
\begin{aligned}
& \dot{\boldsymbol{x}}_{r}=\boldsymbol{A}_{r} \boldsymbol{x}_{r}+\boldsymbol{B}_{r} r \\
& \boldsymbol{y}_{\boldsymbol{w}}=\boldsymbol{C}_{r} \boldsymbol{x}_{r} \\
& \boldsymbol{x}_{r}=\left[\begin{array}{lllll}
\boldsymbol{x}^{T} & u_{2} & u_{1} & u_{3}
\end{array}\right]^{T}
\end{aligned}
$$

$\boldsymbol{A}_{r}=\left[\begin{array}{cc}\boldsymbol{A} & \boldsymbol{B} \\ \mathbf{0}_{3 \times 9} & \mathbf{0}_{3 \times 3}\end{array}\right], \quad \boldsymbol{B}_{r}=\left[\begin{array}{ccc}\mathbf{0}_{9 \times 1} & \mathbf{0}_{9 \times 1} & \mathbf{0}_{9 \times 1} \\ k_{2} & 0 & 0 \\ 0 & k_{1} & 0 \\ 0 & 0 & k_{3}\end{array}\right]$,

$C_{r}=\left[\begin{array}{ll}I_{3 \times 3} & 0_{3 \times 9}\end{array}\right]$

なお, 状態 $x_{r} \in R^{12}$ の中には測定可能な状態变数が 含まれるが，観測ノイズに強い制御系を構成するため, ここでは, $x_{r}$ のすべての状態変数を後述する外乱推定 オブザーバ(同一次元オブザーバ)により推定する(一般 に，同一次元オブザーバの方が，最小次元オブザーバ よりノイズに強い(8.

$3 \cdot 3$ フィードパック制御系の設計 後述するオ ブザーバにより推定された各要素の温度の微分值およ び要素間の温度差とその微分値をフィードバックして, 
ウェハ面内温度を速やかに目標温度に整定させるフィ ードバック制御系を考える. 薄膜ヒータへ供給可能な 電力を最大限利用して, ウェ八面内温度をオーバーシ ュートなく速やかに目標温度に整定させるためには, フィードバックゲインの固定された制御系では不十分 である．例えば，目標温度までの到達時間を短くする ようなフィードバックゲインを適用した場合, ウェハ 温度は，オーバーシュートを生じてしまう。一方，全 くオーバーシュートの生じないフィードバックゲイン を適用した場合, 目標温度までの到達時間が長くなつ てしまう。そこで, 本報では, ウェ八温度の状態に応 じて, 適切なフィードバックゲインを切り換えるゲイ ンスケジュールド制御系を提案する. ウェ八温度の状 態は, 図 5(b)の加熱/冷却一体形プレートを用いた場 合のウェ八温度軌跡とプレート温度軌跡において, プ レート温度がウェ八加熱目標温度に到達するまでの加 熱過渡状態, ウェ八温度が加熱目標温度 $\left.-0.22^{\circ} \mathrm{C}\right]$ に到 達するまでの過渡状態から定常状態への加熱遷移状態, 加熱定常状態, プレート温度が冷却液流量を $6[1 / \mathrm{min}]$ から $3[\mathrm{l} / \mathrm{min}] に$ に切り換える温度に到達するまでの冷却 過渡状態, ウェ八温度が冷却目標温度 $\left.+0.11^{\circ} \mathrm{C}\right]$ に到達 するまでの過渡状態から定常状態への冷却遷移状態, および泠却定常状態に分けられる.

提案するゲインスケジュールド制御系の制御入力 (内部モデルへの制御入力)は, 次式のように表される.

$$
\boldsymbol{r}=K_{p}(w)\left\{v-\boldsymbol{y}_{w}\right\}-\boldsymbol{K}_{v}(w) \dot{\boldsymbol{x}}-\boldsymbol{K}_{e} \boldsymbol{e}-\boldsymbol{K}_{e v} \dot{\boldsymbol{e}}
$$

ここで, 要素間の温度差 $\boldsymbol{e} \in \boldsymbol{R}^{4}$ をつぎのように定義す る.

$$
\boldsymbol{e}:=\left[\begin{array}{llll}
w_{1}-w_{2} & w_{3}-w_{2} & p_{1}-p_{2} & p_{3}-p_{2}
\end{array}\right]^{T}
$$

$\boldsymbol{K}_{v}(\cdot) \in \boldsymbol{R}^{3 \times 9}$ は， ウェ八温度の状態 $w$ によりスケジュー ルされたフィードバック係数行列, $K_{p}(\cdot) \in \boldsymbol{R}^{1}$ は, 比例 ゲインである. $K_{e} \in R^{3 \times 4}, K_{e v} \in R^{3 \times 4}$ は, 固定されたフ イードバック係数行列である. $\boldsymbol{v} \in \boldsymbol{R}^{3}$ は, ステップ状に 与えられる 3つのウェ八要素 $\left(E_{w 3} E_{w \mathrm{~b}} E_{w 3}\right)$ の目標温度(通 常は同一)である.

しかし，3つのウェ八要素 $\left(E_{w 2}, E_{w 1}, E_{w 3}\right)$ の温度分布 を考虑しつつ，干渉を有する多入出力系のフィードバ ックゲインを極配置により決定することは困難である (1 入出力系の場合, フィードバックゲインを $\boldsymbol{K}$ とし て, 閉ループ系 $(A-B K)$ の極の配置により安定性や速 応性を決定できる. 多入出力系の場合, $\boldsymbol{K}$ は唯一に決 定できない，また，干渉を有する場合，まず非干涉化 が必要である) $)^{(}$. そこで, 本報では, ウェ八面内温度 が目標温度 $\pm 0.2\left[^{\circ} \mathrm{C}\right]$ 以内に速やかに収束するように，

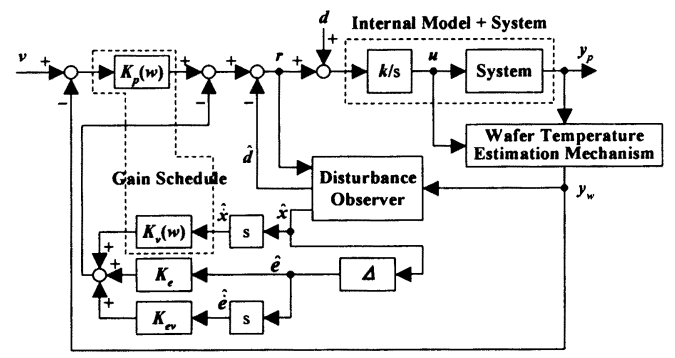

(a) Block Diagram

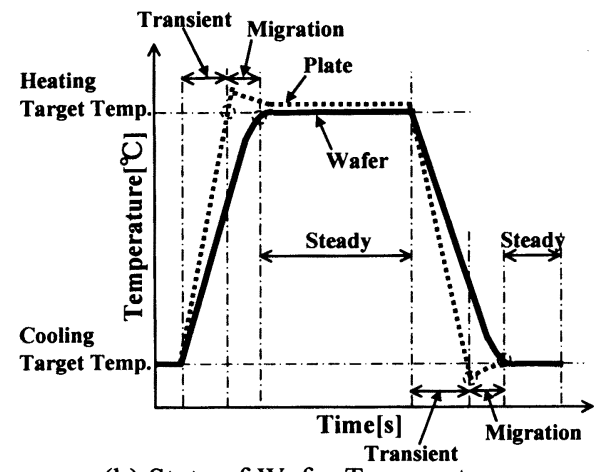

(b) State of Wafer Temperature; w

Fig.5 Proposed Gain Scheduled Control system by State of Wafer Temperature

各状態でのフィードバックゲインをシミュレーション および実験によって試行錯誤決定した(4章に示す). 今後は, 相互干渉に対する非干渉化も含めて, これら フィードバックゲインの設計手法の確立が望まれる.

3.4 外乱推定オブザーバ さらに, モデル化誤 差, プレート内部等への不安定な非定常伀熱, チャン バー温度の変化等の外乱に対して， ロバスト性を高め るために, ここでは, (8),(9)式のサーボ系(内部モデ ルと制御対象を含む)に対して外乱推定オブザーバを 構成する. これによって，上記モデル化誤差等は，す べて内部モデルへの入力信号 $\boldsymbol{r}$ に重畳した外乱とみな される. 外乱推定オブザーバは, 一定值外乱を仮定 (一般に, プロセス制御系では, 外乱の動特性を把握 することが容易でないため)して次式のように構成で きる. その可観測性は, $A_{o}, C_{o}$ からなる可観測行列の 階数が 15 であることによって確認できる.

$$
\begin{aligned}
& \hat{\dot{x}}_{o}=\boldsymbol{A}_{o} \hat{\boldsymbol{x}}_{o}+\boldsymbol{B}_{o} r+\boldsymbol{G}\left\{\boldsymbol{y}_{w}-\hat{\boldsymbol{y}}_{w}\right\} \\
& \hat{\boldsymbol{y}}_{w}=\boldsymbol{C}_{\boldsymbol{o}} \hat{\boldsymbol{x}}_{\boldsymbol{o}} \\
& \hat{\boldsymbol{x}}_{\boldsymbol{o}}=\left[\begin{array}{llll}
\hat{\boldsymbol{x}}_{r}{ }^{T} & \hat{d}_{2} & \hat{d}_{1} & \hat{d}_{3}
\end{array}\right]^{T} \\
& A_{o}=\left[\begin{array}{cc}
A_{r} & B_{r} \\
\mathbf{0}_{3 \times 12} & \mathbf{0}_{3 \times 3}
\end{array}\right], B_{o}=\left[\begin{array}{c}
B_{r} \\
\mathbf{0}_{3 \times 3}
\end{array}\right] \text {, } \\
& C_{o}=\left[\begin{array}{ll}
C_{r} & 0_{3 \times 3}
\end{array}\right]
\end{aligned}
$$




$$
\boldsymbol{G}=\left[\begin{array}{ccc}
g_{1_{-} 1} & g_{1_{-} 2} & g_{1_{-} 3} \\
g_{2-1} & g_{2_{-} 2} & g_{2_{-3}} \\
\vdots & \vdots & \vdots \\
g_{15_{-} 1} & g_{15_{-} 2} & g_{15_{-} 3}
\end{array}\right]
$$

ここで, $\hat{\boldsymbol{x}}_{\boldsymbol{o}} \in \boldsymbol{R}^{15}$ は, 入力に重畳した外乱 $\hat{\boldsymbol{d}}=\left[\begin{array}{lll}\hat{d}_{2} & \hat{d}_{1} & \hat{d}_{3}\end{array}\right] \in \boldsymbol{R}^{3}$ を含む状態の推定值, $\hat{\boldsymbol{y}}_{w} \in \boldsymbol{R}^{3}$ は出力(ウェハ温度)のオブザーバによる推定值である. オブザーバゲイン $G \in R^{15 \times 3}$ は，極配置法により求め る. オブザーバの極は，観測ノイズに対する感度を考 慮して, つぎのように配置した。

$$
\begin{aligned}
& {\left[\begin{array}{lllllll}
-5.1 & -4.4 & -2.9 & -0.68 & -0.53 & -0.11 & -0.13
\end{array}\right.} \\
& \left.\begin{array}{llllllll}
-0.13 & -0.26 & -0.90 & -0.90 & -0.90 & -4.0 & -3.9 & -3.8
\end{array}\right]
\end{aligned}
$$

推定された外乱をフィードバックすることにより， (12)式の制御入力 $\boldsymbol{r}$ は, 新たに次式のように書き換え られる(ただし，(20)式は，オブザーバにより推定さ れた状態を用いて記述する).

$$
\begin{gathered}
\boldsymbol{r}=K_{p}(w)\left\{v-\boldsymbol{y}_{w}\right\}-\boldsymbol{K}_{v}(w) \hat{\dot{\boldsymbol{x}}} \\
-\boldsymbol{K}_{e} \hat{\boldsymbol{e}}-\boldsymbol{K}_{e v} \hat{\dot{\boldsymbol{e}}}-\hat{\boldsymbol{d}}
\end{gathered}
$$

以上をまとめてブロック線図で表すと図 5(a)のように なる. 図中の $y_{p} \in R^{3}$ は, プレート内部にある 3 つの 白金測温抵抗体により計測された温度， $\Delta \in \boldsymbol{R}^{9 \times 4}$ は， 推定された各要素の温度 $\hat{x} \in \boldsymbol{R}^{9}$ から要素間の温度差 $\hat{e}$ を得るための係数行列である.ただし，図 5(a)には, 後述するウェハ温度推定器が含まれている. また, 図 5(a)の積分器には, 制御対象への入力 $\boldsymbol{u}$ (供給電力) の 飽和によるワインドアップを抑制するため, 上下限值 が設けられている.

\section{4. 実匰}

提案する制御手法の効果を確認するために，ウェハ 全面に 20 個の白金測温抵抗体が取り付けられた 200[mm]測温ウェハ(SensArray Wafer ; センサレー社製) を用いて実験をおこなった結果を示す。

また，ここでは，システム同定理論を応用することに よって, インプロセスのウェハ温度を計測可能なプレー ト温度から推定するウェハ温度推定器を提案し, その有 效性を確認した結果を示す。

4.1 ウェハ温度の制御性能 まず，提案手法に よるウェハ温度の制御性能を把握するため, 測温ウェ 八上の 3 個の白金測温抵抗体(図 4 のウェ八要素に対 応する 3 個)を用いて温度制御した実験結果を図 6 に 示す.このとき，シミュレーションおよび実験によっ て決定したフィードバック係数行列および比例ゲイン は,つぎのようである.

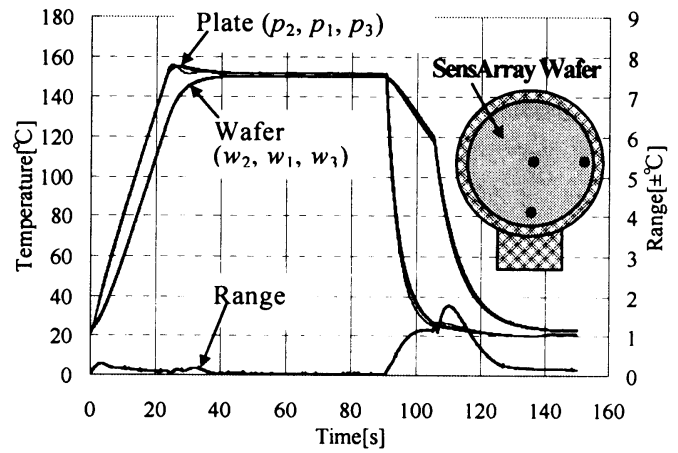

(a) Temperature loci of Wafer and Plate

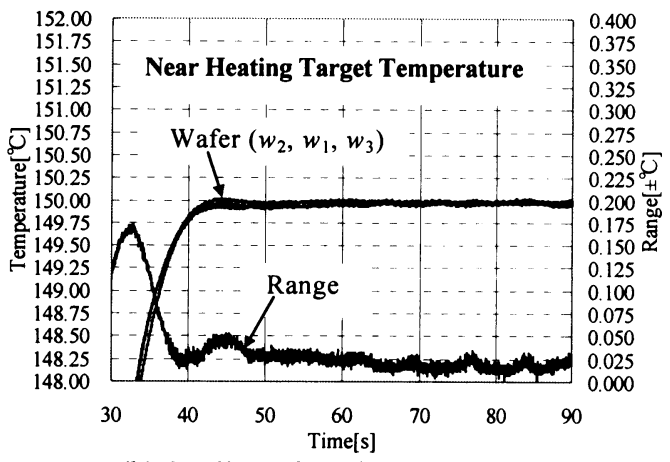

(b) Settling of Wafer Temperature

Fig.6 Experimental Results (Control Performance of Proposed Method)

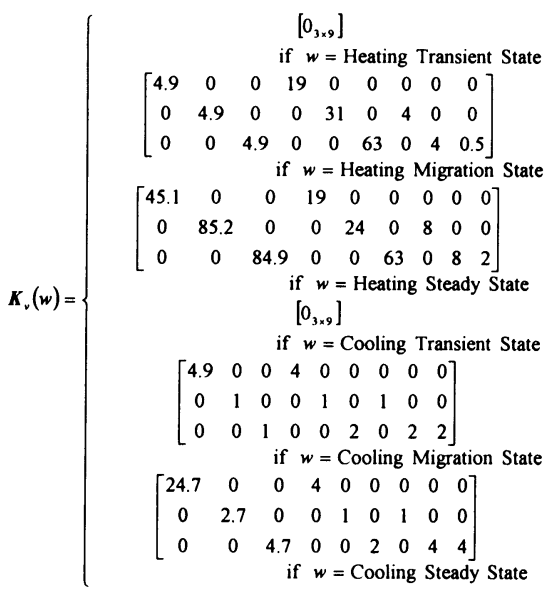

$K_{p}(w)= \begin{cases}1.0 & \text { if } w=\text { Heating State } \\ 2.5 & \text { if } w=\text { Cooling State }\end{cases}$

$K_{c}=\left[\begin{array}{llll}0 & 0 & 0 & 0 \\ 2 & 0 & 8 & 0 \\ 0 & 2 & 0 & 8\end{array}\right], \quad K_{e v}=\left[\begin{array}{llll}0 & 0 & 0 & 0 \\ 4 & 0 & 8 & 0 \\ 0 & 4 & 0 & 8\end{array}\right]$

ただし，内部モデルの積分器のゲインは $\boldsymbol{k}=\left[\begin{array}{lll}46.2 & 12.3\end{array}\right.$ $5.7]^{T}$ とする. 制御演算のサンプリング周期は, $25[\mathrm{~ms}]$ と した.

図 6は，常温のウェハを $\left.150{ }^{\circ} \mathrm{C}\right]$ に加熱した後，搬 
送することなく同一チャンバー内で $23\left[{ }^{\circ} \mathrm{C}\right]$ に冷却した 場合の実験結果である.このとき, 薄膜ヒータへの最 大供給電力は, $3.3[\mathrm{~kW}]$ に制限されている. また, 冷 却開始時において, ウェハは, 昇降ピンを駆動するこ とによって, プレート表面から $1.5[\mathrm{~mm}]$ 持ち上げられ る. その後, ウェ八温度が所定温度(図 6 の場合, $120\left[{ }^{\circ} \mathrm{C}\right]$ 以下になると, 元の状態(ウェハがプレートに 載せられた状態)に戻される。これは，プレートへの 冷却液供給が開始された直後に生じるウェハ面内温度 分布を低减するためにおこなわれる.

図6から，加熱時には，大きな相互干涉，不安定な 非定常伝熱, および伝熱の遅れが存在するにもかかわ らず，提案手法によって，ウェ八の高速加熱と同時に オーバーシュートのない良好な制御性能が得られてい ることがわかる. 薄膜ヒ一タには負の入力がないため $(\boldsymbol{u} \geq 0)$, ウェ八温度を速やかに目標温度に整定させる ことは非常に困難であるが，提案されたゲインスケジ ユールド制御によって実現できている．図中の Range $\left[ \pm^{\circ} \mathrm{C}\right]$, ((最大温度)一(最小温度) $) 2$ のように定 義されたウェ八面内温度分布を表す值である. ただし， 図 6 の Range は, 測温ウェ八上の 3 点のみの值である.

$4 \cdot 2$ ウェハ温度推定器 実プロセスにおいて, ウェハ温度の高精度なインプロセス計測は, 実現され ていない 9 (10．赤外線放射温度計は, 赤外線がウェハ を透過するため用いることができない. また, 光ファ イバーを用いた温度センサでは, 計測精度が十分でな く，また，高価なため用いることが困難である.

そこで, 本報では, 図7のように, 計測可能なプレ 一ト温度を用いて, ウェ八温度を高精度に推定するウ エ八温度推定器を提案する ${ }^{(11)}$. ウェ八温度推定器は, 計測されたプレート温度およびゾーン 2 の薄膜ヒータ への供給電力(ただし，実測值ではなく，計算值)を入 力, 推定されるウェ八温度を出力とする状態空間モデ ルで記述される(図 4 のウェ八要素に対応して，3つ のウェ八温度推定器がある). 薄膜ヒータへの電力を モデルに考虑するのは, 薄膜ヒータからウェハへの伝 熱に対して，プレート内部にある白金測温抵抗体によ り計測された温度が時間遅れを有し，これを補償する 必要があるためである.

状態空間モデルは, 4・1 節と同様の測温ウェ八を用 いた実験結果からシステム同定により求める. 具体的 には, 3 つのウェ八要素それぞれに対して, 測温ウェ 八を用いて計測された温度とウェ八温度推定器( 状態 空間モデル)の出力をフィッティングすることによっ て, モデルの次数および各係数行列を決定する. ただ し, 各係数行列は, プレート/ウェ八間の伝熱特性の

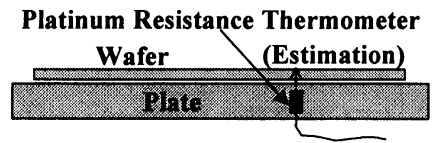

Fig.7 Estimation of Wafer Temperature

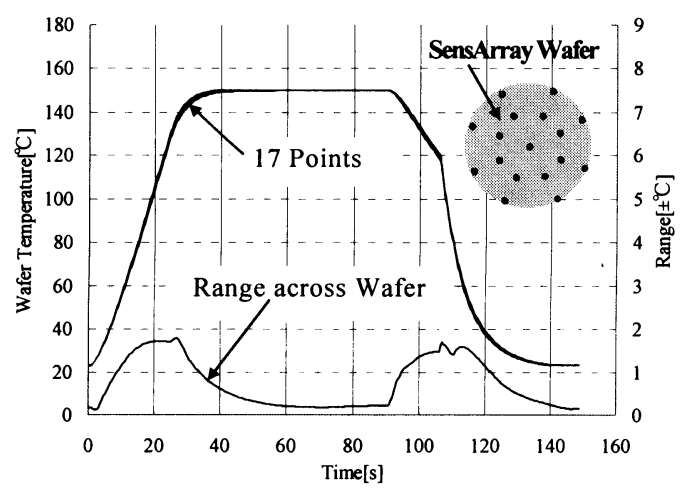

Fig.8 Experimental Result Using Wafer Temperature Estimation Mechanism

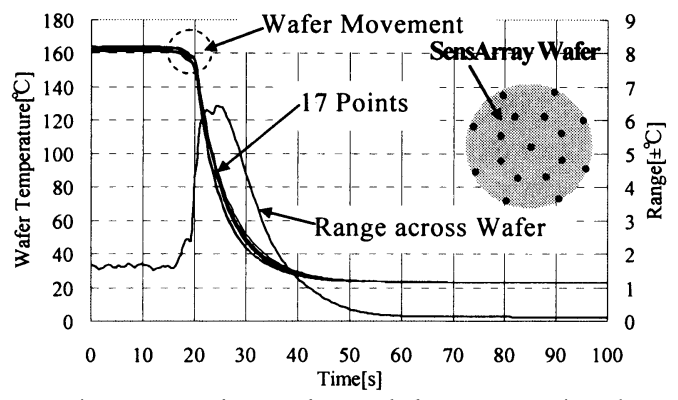

Fig.9 Experimental Result by Conventional Cooling Plate

変化を考慮して, 加熱状態, 冷却時のウェハが昇降ピ ンにより持ち上げられている状態，その後の液冷状態， および夜冷と薄膜ヒータによる温度制御状態で異なる。 さらに, 各係数行列は, 加熱目標温度および加熱速度 で異なる. これは, 加熱目標温度および加熱速度に対 する非線形性(加熱温度に対するウェ八上面の自然対 流の影響等)を考慮して, より正確なウェ八温度の推 定を実現するためである. そして，プロセス中にそれ ぞれの状態に対応した状態空間モデルを選択し, ウェ 八温度を推定する.

以上をまとめてウェハ温度推定器を可変構造の状態 空間モデルとして表すと, 次式のようになる.

$$
\begin{aligned}
& \dot{\boldsymbol{x}}_{\text {est }}=\boldsymbol{A}_{\text {est }}(\text { (state,Target,Ramp }) \boldsymbol{x}_{\text {est }}+\boldsymbol{B}_{\text {est }}(\text { State, }, \text { arget,Ramp }) \boldsymbol{u}_{\text {est }} \\
& y_{\text {est }}=\boldsymbol{C}_{\text {est }}(\text { Slate, }, \text { arget, Ramp }) \boldsymbol{x}_{\text {est }}
\end{aligned}
$$

ここで, $\boldsymbol{u}_{e s t} \in \boldsymbol{R}^{2}$ は，計測されたプレート温度と計算さ れた電力からなる入力, $y_{e s t} \in \boldsymbol{R}^{1}$ は, ウェ八温度推定器 の出力である. 紙面の枚数の都合上，ここでは詳細なす べての $A_{e s t}(\cdot), B_{e s t}(\cdot), C_{e s t}(\cdot)$ O值を示さないが, その次 
数は，それぞれの状態に対して異なる(状態 $x_{81}$ の次数に 関しても同様).

提案されたウェハ温度推定器を用いて, ウェハ温度 を制御した実験結果を図 8 に示す。ただし，図 8 は, 測温ウェハ上の 17 個の白金測温抵抗体を用いて，ウ エハ面内温度分布を計測した結果である(図 6 は, 3 点 のみ). 図 8 から, 提案されたウェ八温度推定器によ って, インプロセスのウェ八温度が正確に推定され, 良好なウェ八面内温度分布の制御が可能であることが わかる。

一方, 従来の冷却プレートを用いた場合の実験結果 の一例を図 9に示す．図 8,9を比較することによって, 加熱泠却一体形プレートを用いた場合, 冷却過渡状 態に生じるウェ八面内の温度差が, 従来の $1 / 4$ に低减 されていることがわかる.ここでは詳細を述べないが, 加熱過渡状態においても同様の性能改善が見られる.

今後は, 目標温度近傍でのウェ八面内温度分布の収 束性改善(プレート構造および製作に起因)とチャンバ 一温度の変動や平面度の違うウェハ等に対するウェハ 温度推定器の適応性, ロバスト性の向上が必要である.

\section{3 ウェハ温度推定器を用いた任意熱鹿歴制御}

つぎに，加熱冷却一体形プレートを用いることによ って実現可能となるウェ八毎の任意熱履歷制御の実験 結果を図 10,11 に示す. 図 10,11 は, それぞれウェハ 毎に加熱目標温度および加熱速度を変更した場合の実 験結果である. ここで, ウェ八の加熱速度は, 加熱過 渡状態における $3 つ$ づーンの薄膜ヒータへの最大供 給電力を制限することによって変化させた. 図 10,11 から, 加熱目標温度および加熱速度を変化させた場合 でも, 提案されたウェ八温度推定器によって,インプ ロセスのウェ八温度が正確に推定され，良好なウェハ 面内温度分布の制御が可能であることがわかる。これ より, 提案手法によって, ウェ八上の種類や性質の異 なるレジストに対して，任意の熱履歴を容易に与える ことができる.

\section{5. 結言}

大きな相互干渉を有する多入出力系の半導体製造用 加熱冷却一体形プレートに対して，その伝熱特性の 違いにより最小限に要素分割された有限要素伝熱モデ ルを用いたゲインスケジュールド制御系を提案し，そ の有効性を実験により確認した. また，インプロセス 計測が困難なウェ八温度を, 計測可能なプレート温度 を用いて推定するウェ八温度推定器を提案し, その有 効性を実験により確認した. そして, 提案手法によっ

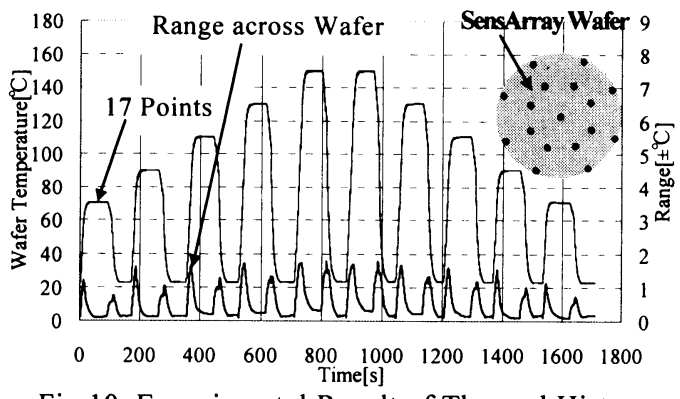

Fig.10 Experimental Result of Thermal History Control (Change of Heating Target Temperature)

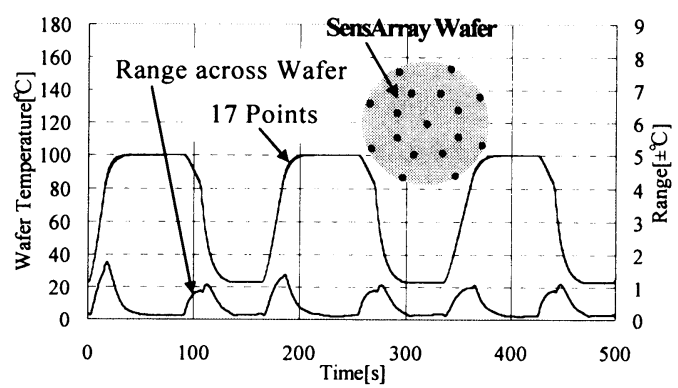

Fig. 11 Experimental Result of Thermal History Control (Change of Ramp Rate)

て, 従来の加熱冷却システムでは, 実現が困難であ った精密なウェハの任意熱履歷制御が可能になった. 今後の課題は, 相互干渉に対する非干涉化も含めた制 御系設計手法の確立とウェ八温度推定器の適応性, 口 バスト性の向上である.

\section{文献}

（1）木浦成俊， 2003 半導体工場・装置・材料， (2003)， 188-194， 電子ジャーナル。

(2) 木浦成俊, 2002 半導体テクノロジー大全, (2002), 193-206, 電子ジャーナル。

(3) 板東堅一・福原聁・横田直一，むた時間を有するプロセスに対 する離散時間スライディングモード制御と半導体製造用クーリング プレートへの適用, 日本機械学会論文集 C 編, 69-682(2003), 1587-1594.

(4) 板東督一・福原聡・横田貞一，モデル規篹形スライディングモー ド制御を応用したマスター・スレーブ制御（マルチソーン形クーリ ングプレートの温度軌跡追従制御)，日本機械学会論文集 C 編，70696(2004), 2329-2336.

(5)箵原興二, '回最新半導体プロセス技術，(2001)，78-81，プレ (6) Khalid El-Awady, Charles D. Schaper, and Thomas Kailath, Integrated Bake/Chill for Photoresist Processing, IEEE Transactions on Semiconductor Manufacturing, 12-2 (1999), 264-246.

(7) 白石昌武, 入門現代制御理論, (1987)，148-155, 啓学出版. (8) 岩井善太・井上昭・川路茂保, オブザーバ, (1988)， 119-123, コロナ社.

(9) 中痛行 ·佐竹司 · 大柣久仁夫, シリコンウェハの温度計測用ラマ ン分光システムの性能改善, 第 64 回応用物理学会学術講演会予稿 集, (2003-9), 2a-ZH-8.

(10) 佐々湰史 - 池田純一 - 菊田和重 - 菱沼孝夫 - 近久武美, サフ アイアロッドによる積層型過熱炉内ウェ八温度計測, 第 38 回日本 伝熱シンポジウム講演論文集, (2001-5), C214.

(11) 板東堅一，基板温度推定装置及び方法並びにそれを用いた基板 温度制御装置，公開特許公報特開 2000-235944，(2000-8). 